\title{
A DESOBLITERAÇÃO DA SIMBÓLICA COMO TAREFA DA BIOÉTICA
}

\section{The desobliteration of symbolic as a task to bioethics}

\begin{abstract}
Nilo Ribeiro Junior
Doutor em Teologia pela Faculdade Jesuíta de Filosofia e Teologia, mestre em Teologia Moral pela Pontificia Università Gregoriana, diretor do Departamento de Teologia da Faculdade Jesuíta de Filosofia e Teologia (FAJE), professor assistente da Faculdade Jesuíta de Filosofia e Teologia (FAJE), Belo Horizonte, MG - Brasil, e-mail: niloribeiro@ faculdadejesuita.edu.br
\end{abstract}

\section{Resumo}

Este artigo visa a refletir sobre a questão da bioética no contexto da cultura contemporânea marcada pelo "esquecimento" da simbólica. Essa última diz respeito, sobretudo, à linguagem e se associa à emergência do sujeito/palavra no ato performativo da fala e na relação com o outro humano. Na medida em que a palavra perde sempre mais espaço para a avalanche de linguagens ostensivas sobre o real - de tipo cientificista e juricizante - o indivíduo se torna um epifenômeno e, consequentemente, desaparece como sujeito da ação moral. Nesse contexto, a irrupção da alteridade, rosto e palavra humana irredutíveis aos discursos sobre o outro, emerge como chance para tirar o mundo da linguagem do esquecimento. Abre-se a possibilidade de falar e de agir em vista do outro. Ressurge uma nova simbólica em função do cuidado da vida do outro, a bioética.

Palavras-chave: Esquecimento. Ética. Sujeito actante. Linguagem. Alteridade. 


\section{Abstract}

This article considers bioethics in the context of contemporary culture, marked by the forgetting of symbolic. Symbolic concerns specially language and is associated to the emergence of the subject/word in the performative act of speech and in the relation to another human being. As the word increasingly loses ground to the avalanche of ostensive languages - of scientific and juridical kind - that falls upon the Real, the individual subject becomes an epiphenomenon and consequently disappears as the subject of moral action. In this context the irruption of alterity - the face and the human word irreducible to discourses about the other-emerges as the chance to rescue the world out of the language of forgetting. The possibility of speaking and acting in behalf of the other is opened. Bioethics rises as a new symbolic with the purpose of taking care of the life of the other.

Keywords: Forgetting. Ethics. Actant subject. Language. Alterity.

\section{INTRODUÇÃO}

Vivemos sob o signo de uma cultura que, em certo sentido, confirma a profecia dos estruturalistas a respeito da "morte do homem". O homem moderno, movido pelas grandes narrativas, palavras, utopias, pelo mito do progresso e pela força da autonomia, está em vias de desaparecer. Com isso se assiste a um adeus à moral moderna (ETCHEGOYEN, 1999, p. 39), calcada sobre o sacrifício de Prometeu que, mesmo castigado pelos deuses, deu aos homens a razão para captar o mundo e a técnica para transformá-lo. Nesse sentido, Narciso tem sua razão de ser: é melhor gozar do que sofrer! Estamos, assim, na eminência de nos desfigurarmos ou diante da possibilidade do florescimento de uma nova ética? (HAMONIC, 1998, p. 141).

Este trabalho quer lançar uma reflexão sobre o fato de que a simbólica como linguagem do símbolo esteja em vias de ser esquecida na cultura contemporânea (BAUMAN, 1999, p. 32). Talvez o motivo principal desse esquecimento ou dessa obliteração se deva ao fato de as linguagens ou as denominadas metalinguagens terem assumido um caráter impessoal e, em certo 
sentido, tecnicista e juricizante sobre o real. Revelam dessa maneira um fenômeno inquietante, a saber, uma espécie de desaparecimento do sujeito da fala e o sujeito que fala. Restam os discursos sem sujeitos. Compromete-se a capacidade do ser humano de agir. É a esse fato que associamos a morte do homem. Na perspectiva performativa da linguagem, a fala está associada imediatamente à ação e, por isso mesmo, à ética. Falar é agir, e agindo o sujeito que fala se faz na práxis!

Entretanto, mostraremos que no contexto da cultura pós-moderna, por um lado, vem reforçada a tese do desaparecimento do humano como sujeito da fala, mas, por outro, emerge, como nunca, a vulnerabilidade do ser humano. Pensamos que essa condição abre caminho para a "re-significação" da simbólica. Há indícios de que nessa situação hiperbólica, a alteridade aparece interpelando como nunca nossa cultura. Quando Narciso frágil perdeu todas as pretensões prometeicas de assimilar o real pela razão e quando passou a ver, no mundo produzido por ele, refletida apenas sua própria imagem, acentua-se um hiato entre ele e o que não é espelho. Nesse ínterim o outro, na sua vulnerabilidade e nudez, pode colocar um fim no emudecimento ou na morte do humano ao modo pós-moderno.

Quando o outro irrompe, o indivíduo que se compraz em si é lançado para fora de sua imagem. De algum modo se sente compelido a agir. Redescobre a capacidade de agir graças à interpelação da relação. Nesse caso, a responsabilidade ética reaparece com traços surpreendentemente novos. $\mathrm{O}$ ressurgimento da responsabilidade no contexto da cultura contemporânea repercute imediatamente no âmbito da bioética. Com isso pretende-se mostrar que a Bioética é o campo privilegiado do saber em que a responsabilidade ética em seu caráter pessoal e coletivo pode tirar a simbólica da obliteração.

No primeiro passo da reflexão, trata-se de apresentar algumas consequências às quais conduz a crítica da modernidade feita pelos estruturalismos ainda hoje em voga. Apontam para um elemento comum: a instrumentalização e a tecnicização do ser humano e do mundo, e ao mesmo tempo, uma aversão à ciência e à técnica. Na medida em que desaparece o ser humano ação/palavra e se impõem as linguagens anônimas, essas tendem a assimilar o método empírico-formal para construir um discurso da previsão e eficácia sobre o humano e o mundano. Por outro lado, as mesmas linguagens assumem um caráter que se prefere denominar aqui de alegorizante, isto é, reivindicam para si uma imunidade e um distanciamento das ciências empíricas. 
Fabricam teorias sobre a vida que se contrapõem aos reais modos de viver. Pretendem evitar a "contaminação" do sensível ou a "queda" no cotidiano como ocorreria com as outras ciências. Trata-se, como se perceberá, de um paradoxo tecnolinguístico. Buscam a técnica para se legitimarem, mas se subtraem do mundo da técnica pela linguagem. Esse paradoxo repercute sobre a subjetividade e, consequentemente, sobre as chamadas ciências da vida - e mais, sobre a própria maneira como a ética tem assumido um caráter técnico e juricizante em nossa cultura.

\section{As linguagens ostensivas da cultura contemporânea}

A primeira constatação sobre a tecnicização do real aparece em função da tendência dos discursos ultramodernos em se tornarem metalinguagens. Como foi dito anteriormente, o caráter metalinguístico está associado à preocupação exaustiva pela pragmática e pela lógica interna do discurso. Isso faz com que esses discursos abstraiam a existência do protagonista na fala.

\section{O homem como epifenômeno}

O homem contemporâneo tornou-se refém do anonimato da pluralidade das linguagens criadas pela própria modernidade. Hipostasiadas do sujeito da fala, consideram seu criador um epifenômeno. O sujeito concreto perde a relevância na engrenagem de seu discurso. O que menos lhes interessa é que o sujeito fale, que aja, e que, portanto, nasça (ARENDT, 2002, p. 189). Parece que é chegado um tempo em que a aparência dos discursos revela a pura evanescência do humano. Esse caráter aniquilante das linguagens tende a expurgar o que não se enquadra na sua lógica. Experimenta-se mormente uma espécie de onipotência ao reverso da modernidade. O discurso unívoco do Saber foi substituído por tantos outros mais sutis e difusos, mas não menos pretensiosos do que aquele da razão. Se na modernidade se impôs o metarrelato da razão, atualmente assistimos à fragmentação de discursos que não são menos apologéticos do que aquele, mas que, ao mesmo tempo, admitem certa perplexidade diante de qualquer tentativa de articulação desse pluralismo. Trata-se de uma aporia. Tais discursos se especializaram em dissecar o humano através de suas diversas e complexas 
expressões, mas se tornaram linguagens sem sujeitos, sem pessoas. Fizeram-se à custa da sofisticação dos métodos das ciências empírico-formais, os quais não poupam sequer um átomo de descrição e explicação desse objeto. Há por isso uma crescente busca do cálculo, da programação, da previsão, do planejamento, da eficácia a respeito do humano. Torna-se impossível negar o fato de as linguagens "sobre" o real assumirem um caráter sempre mais utilitarista.

\section{O risco e a palavra}

A situação é bem diferente quando o sujeito emerge na fala. Ao contrário do pragmatismo, o sujeito introduz o risco no mundo com a sua ação. Com isso mantém certa incerteza quanto ao seu futuro que os discursos sobre a ação não podem jamais conter e estancar. Através da fala, o sujeito agente interrompe a lógica do engessamento dos discursos sobre o homem e o mundo. É precisamente nesse contexto que aparece o paradoxo das metalinguagens. Estão à procura de uma maior confiabilidade em relação às atividades humanas, a fim de que o homem não fique vulnerável diante do agir e dos outros. Por outro lado, elas, que buscam controlar a lógica da ação humana e lhe oferecer mais segurança, não admitem a ingerência dos métodos empíricos nesse ordenamento da ação.

Se, por um lado, as linguagens se travestem de eficácia exigindo o mínimo de interferência do sujeito da fala, por outro, negam qualquer ingerência do estatuto tecnocientífico ao se recusarem a ser identificadas à lógica da técnica, uma vez que pretendem se manter no âmbito do simbólico, isto é, do eminentemente linguístico. Em suma, quando o discurso se desvincula do locutor da palavra que é o próprio ser humano como sujeito da fala, a linguagem perde sua trama original, ou seja, aquela em que o homem se autoproduz na linguagem e ao mesmo tempo na técnica.

\section{Metalinguagens a-simbólicas}

Atualmente, não é incomum deparar-se com a tendência das linguagens sobre as denominadas "ciências da vida" de se tornarem avessas a qualquer operacionalidade. Reivindicam a absoluta autonomia quanto ao tratamento das questões do sentido e da significação do real e, por isso, não 
poucas vezes ridicularizam o caráter experimental e explicativo das ciências empírico-formais que, no fundo, adotaram para si.

Entretanto, esse fenômeno ocorre porque as metalinguagens necessitam do símbolo ${ }^{1}$ para poder ressignificar sua pretensão de ser linguagem - é próprio da linguagem desejar propugnar-se como construtora de símbolo - e ao mesmo tempo têm a preocupação de ser pragmáticas - é próprio da linguagem atingir certa eficácia, de querer ser transformadora, ver resultados, etc. O símbolo, sendo da ordem da ação/palavra, contempla tanto o risco como o cálculo, como veremos ao longo dessa reflexão. A simbólica como linguagem do símbolo pode ser tirada do esquecimento quando seu discurso não dissocia a dimensão linguística da dimensão tecnopoiética.

\section{A técnica da felicidade ou a felicidade da técnica?}

Uma perda lastimável se configura quando a linguagem perde seu caráter simbólico e se torna meramente técnica. Nesse sentido, as linguagens "sobre" o real têm como escopo minimizar qualquer "perigo" de acidente de percurso e, consequentemente, maximizar o controle e a segurança de que seus destinatários terão pleno êxito em todos os negócios. Quanto menos equívoco, mais felicidade terá o ser humano! Assim a cultura contemporânea propugna a "felicidade sem eudemonia". Ela está associada a um aspecto, em certo sentido degenerativo, daquilo que Aristóteles denominava de poiésis.

\section{A fabricação do corpo sem sujeito}

Há atualmente uma reinvenção pós-moderna da felicidade em sua versão despersonalizante, seja porque é instrumental, seja porque se mostra também avessa à eficácia. Essa aparece sobremaneira na fabricação do corpo

1 A definição e o significado do Símbolo a que nos referimos aparecem de maneira explícita no item Expressões da cultura juricizante.

2 Eudemonia, na visão de Ricoeur (que, por sua vez, reinterpreta Aristóteles na esteira da filosofia hermenêutica), significa o bem viver com-e-para-os-outros-no-mundo. Eudemonia, portanto, está associada à relacionalidade e à vida pública. Ela se opõe à visão de autorealização individualista ou solipsista.

Rev. Pistis Prax., Teol. Pastor., Curitiba, v. 2, n. 1, p. 13-40, jan./jun. 2010 
sem humanidade. A obra está especialmente associada ao domínio e à manipulação de um corpo melhor que o denominado corpo próprio, no qual nos exprimimos e vivemos com os outros no mundo. Entretanto, verifica-se que a produção do corpo não pretende nada mais do que o mero gozo. Lipovetsky não deixa de ter razão quando afirma que o preocupante nesse fenômeno tipicamente pós-moderno não é a "dessensualização nem a ditadura do prazer, mas a fragilização das personalidades" (LIPOVETSKY, 2004, p. 83). Esse seria o problema da poiésis - técnica do humano desacoplado do sentido que vem pela práxis, em que o sujeito é o sentido da ação.

\section{A separação entre poiésis e práxis}

A práxis, ao contrário, reconstitui a cada momento a personalidade e a identidade do que somos "como" corpo. Nela há sempre lugar para a individuação - identidade e ipseidade - e para a humanização de nossa humanidade. A práxis é impensável sem o protagonista ou sem o ator que se faz no agir e no discurso. O sujeito actante jamais pode eliminar de seu horizonte a imprevisibilidade graças ao fato de que ele, ao se criar na ação, perde certo domínio sobre a criação.

Se na filosofia antiga não havia concorrência entre a simbólica e a técnica, dada a profunda intriga existente entre ambas, nas metalinguagens da cultura pós-moderna acentua-se o paradoxo iniciado na modernidade. Tais linguagens aniquilam o sujeito da fala e ao mesmo tempo the prometem o controle de uma felicidade do conforto e do bem-estar para um corpo ávido de saciedade, satisfação e maior proteção. Essa lógica tem sérias repercussões, especialmente no âmbito das questões que dizem respeito à vida humana em seus momentos mais vulneráveis. As técnicas sofisticadas sem a simbólica da ação, aplicadas ao início e ao fim da vida, ou a medicalização da saúde em todos os níveis, com vistas à denominada "qualidade de vida" a qualquer preço, acabam sendo expressão do que denominamos como obliteração da simbólica. O problema não está na técnica como tal. Ela tem seu valor extremamente simbólico e, portanto, pode cumprir a função humanizante para a vida de todos. Tanto ela como as ciências foram plasmadas pelas nossas mãos. O problema está em dissociá-la do símbolo-palavra e do simbólico que subjaz à técnica. 
RIBEIRO Jr., N.

\section{A obliteração no culto de Narciso}

A obliteração ou o apagamento da simbólica, associa-se a um fato sem precedentes na história. O homem está sendo imobilizado e esvaziado na sua capacidade de falar e de agir, e de, agindo, fazer-se na palavra. Essa situação tem tomado contornos muito precisos tanto na linguagem como na técnica. Atualmente o imaginário do humano que se constrói a partir das linguagens tecnicizadas passou a ditar as normas e os padrões de perfeição, de ideal, performance, de maior produtividade, de estetização extravagante do corpo e do que decorre delas em vista do maior rendimento e da vantagem de quem o possui. Trata-se não mais do sacrifício imposto pela razão, mas da bioascese ou da ânsia de ter de produzir a qualquer custo um corpo sem palavra projetado para não sofrer, não desgastar, não morrer jamais.

\section{A auto-poiésis sem alteridade}

Há hoje um culto ao homem narcísico que "se produz"; poiéticonarcísico. Toma contornos próprios graças à sofisticação da técnica que se independentiza do simbólico, e do simbólico que se tornou indiferente à técnica. Esse fabricador de si tem conseguido uma margem crescente de sucesso na interferência nos processos daquilo que constitui o especificamente humano do ser humano. Essa situação o faz projetar sobre si e sobre os outros que hão de vir o ideal da produção que a técnica tem prometido e possibilitado realizar. Com isso, o ser humano e o próximo são pensados em função daquilo que podem realizar agora no presente e poderão reivindicar para seu futuro: desfrutar de uma felicidade sempre mais quantificável segundo a qualidade da poiésis dissociada da simbólica da palavra.

A eugenia não parece ser algo do mundo da ficção. Trata-se, na verdade, do cultivo do homem sem Nome e sem finitude à imagem do corpo sem rugas e nem manchas em todos os sentidos. Certa ditadura dos genes pode aqui entrar em cena sem que provoque muito alarde. Entretanto, isso não pode ser atribuído somente à "técnica sem coração", mas à "metalinguagem sem vida". Ela não deixa de confirmar certa tendência de

Rev. Pistis Prax., Teol. Pastor., Curitiba, v. 2, n. 1, p. 13-40, jan./jun. 2010 
uma apologia velada da produção de um corpo (humano?) muito próximo da ficção dos ciborgues, na qual a técnica e metalinguagem são cúmplices. Desse pressentimento os indícios já aparecem na frequente menção aos problemas de "neuroética", decorrentes do desenvolvimento das neurociências, por exemplo. Essa configuração está em vias de negar a possibilidade de o homem poder se simbolizar no seu corpo e de transignificar a técnica em função de sua existência e da dos outros que virão (JONAS, 1992, p. 25).

\section{A felicidade do pós-moderno}

Nesse contexto, parece decisivo reconhecer que do mundo do símbolopalavra advém a humanização da técnica que desumaniza a felicidade. Ora, como a técnica também é da ordem da simbólica, sempre poderá ser ressignificada pelo símbolo. Por isso também, quando aparece religada à ciência (saber), pode se apresentar como crítica às metalinguagens que são capazes de desfigurar o real através das ideologias, teocracias, fundamentalismos, fobias, etc. É, portanto, no âmbito da palavra que acontece a interrupção daquilo que torna o ser humano "ob-sceno" ao ser objetualizado pela poiésis, bem como aquilo que o torna objetivado pela linguagem alegórica do discurso técnico das ciências humanas.

Na palavra e no símbolo, ao contrário, o ser humano se esconde quando fala e se revela quando silencia. É nesse escondimento da palavra e do símbolo que a construção do humano ganha em humanidade. Em outras palavras, somos arrancados do feitiço que a tecnociência mal pensada pode introduzir em nosso imaginário. Não a tomaremos mais como aquela que nos incita a buscar, através do espelho da técnica, uma imagem inédita de um homem quantificável e idealizado. Se ao nos hipnotizar ela poderia nos conduzir à impossibilidade de falar, por outro lado, a possibilidade do emudecimento recorda o fato de que somos os parturientes da ciência e da técnica. Não se trata, portanto, de demonizar a técnica e seus engenhos; seria retrógrado e contraditório esquecer que o que ela traz para a compreensão do homem e do mundo já é patrimônio da cultura. Foi graças à nossa capacidade de significar o real pela palavra que pudemos fazer com que a ciência e a técnica chegassem aos resultados bem-sucedidos nas várias áreas da biotecnologia, biomédica, genética, informática e tantas outras.

Rev. Pistis Prax., Teol. Pastor., Curitiba, v. 2, n. 1, p. 13-40, jan./jun. 2010 


\section{A palavra do sujeito agente}

Trata-se de insistir que fora da palavra iniciadora e mediadora do sujeito (que fala), o homem se torna refém da técnica das linguagens e da linguagem da técnica que ele mesmo criou. Enquanto objeto de sua própria fabricação e da produção tecnicizada de seu futuro, a obra que é o homem se produzindo na poiésis linguística e na técnica, está inelutavelmente protegida das intempéries da vida. No entanto, o fabricado/homem corre o risco de se ver enredado pelas malhas das rígidas regras da racionalidade empírico-formal sancionadas pelo aparato juridicista de nossa cultura.

\section{Expressões da cultura juricizante}

Uma gama de fatores culturais concorre para a configuração do fenômeno da obliteração da simbólica. Vale notar que, quando nos referimos ao símbolo, não estamos tomando-o no sentido clássico, isto é, como algo ou coisa que rejunta duas partes perdidas ou até concorrentes, a fim de unificálas dando novo sentido ao real. Antes, símbolo está associado aqui àquilo que é especificamente humano, ou seja, à palavra, o poder de falar e de "se" dizer com os outros no mundo. Só há símbolo onde acontece a significância de nossa humanidade no dizer da palavra. Nesse sentido, símbolo e palavra são inseparáveis enquanto retratam o "evento" humano. A simbólica é a gramática do símbolo/palavra. Na medida em que as linguagens, incluindo as técnicas, perdem o caráter ancilar do símbolo, acabam por imobilizar e "des-figurar" o agente que fala. Elas se tornam um Dito que reivindica o lugar do Dizer. Isso tem forte impacto sobre a compreensão da responsabilidade ética que tende a descaracterizar-se e assumir feições notadamente jurídicas (ETCHEGOYEN, 1999, p. 27).

\section{O individualismo e a cultura das "seguradoras"}

Todo o aparato juricizante da nossa cultura ultramoderna confirma o diagnóstico supracitado. Ele está encarregado de fazer com que o sujeito se sinta obrigado a responder por tudo e por todos sem que seja tratado como 
aquele que fala. Nos discursos societários sobressai o interesse crescente pela minimização dos perigos de conflitos sociais. A lei, sobretudo, no contexto da galopante privatização da vida pública a partir do individualismo moderno, advoga-se como garantia e direito de que todos possam gozar. Se uns gozam das benesses, outros chafurdam na violência. Afinal, o limite entre o gozo e a dor está por um fio na configuração de nossas sociedades. Infelizmente, encontram respaldo na linguagem do direito ou na jurisprudência quando essas perdem o contato com a dimensão ética do discurso.

$\mathrm{O}$ discurso econômico, que nunca admitiu ingerência na forma de apregoar a autonomia do mercado, tem assumido ultimamente uma roupagem humanística a fim de assegurar que o homo economicus não deixe de associar sua produção ao gosto pelo consumo. Sua lógica é que o "direito" de consumir "garanta" o prazer do possuir. Essa lógica está em ascensão numa "cultura das seguradoras" como a nossa, sobretudo com vista a proporcionar o contentamento tão almejado por aqueles que podem pagar pelos altos custos de seus serviços.

Nessa mesma perspectiva, até a psicanálise, tão em voga em nossa cultura marcada pelo desencanto ou por uma vida sem desejo, não escapa da tendência de juricizar e tornar anônima a responsabilidade. Não é incomum escutar vozes freudistas que apregoam que o que de fato lhes interessa é que o inconsciente não crie "situações incontroláveis" para o indivíduo. A palavra parece estar mais a serviço do domínio da "desalienação" do analisado sobre suas pulsões do que da liberação do "animal falante" do seu medo de "se" dizer e tecer uma nova teia de relações e significações diante da ambivalência de Eros.

\section{O pragmatismo da linguagem e da mídia}

Não com intuito diferente, a pragmática da linguagem abdica, propositadamente, de incluir o homem no campo da semiótica. Não há responsáveis porque a linguagem não pertence a ninguém, embora seja patrimônio de todos. Afinal, o que menos lhe parece producente para o conhecimento é o caráter performativo da linguagem. O sujeito da fala sempre aparece como aquele que "desestrutura" e coloca em "perigo" o que a língua e a linguagem levaram séculos para construir. Além disso, a linguagem midiática, primando pela virtualidade da comunicação, tende sempre mais a tornar anônimo 
RIBEIRO Jr., N.

seu interlocutor. Desaparece a identidade, restam a fluidez e o provisório. A mídia não se cansa de atribuir responsabilidade ao sujeito que caiu na rede quando ele nem mesmo se deu conta de ter aceitado as regras "virtuais" do jogo. Quando percebe, já foi devorado por merchandise de todo tipo. Na maioria das vezes, o sujeito encontra-se incapacitado para decidir e agir, presa fácil desse aparato comunicativo sem sujeitos que falam.

Há, portanto, uma série de fenômenos relacionados à linguagem que não deixam de evidenciar o esquecimento da simbólica. Acabam por dar a impressão de que o homem está em vias de perder de horizonte o caráter eminentemente ético da responsabilidade. Tanto a poiésis técnica como a metalinguagem alegorizante sem a significância da palavra imobilizam o agente. Ele se torna refém do signo sem sentido e se vê impossibilitado de viver significando e "recriando" o real pela palavra iniciadora e mediadora com os outros no mundo.

\section{O esquecimento do esquecimento}

Essa situação poderia ser traduzida por aquilo que Ricoeur denominou de esquecimento epocal (RICOEUR, 1988, p. 29). Nossa época é marcada pelo alheamento do Ser, do Outro, da vida e, enfim, da simbólica.

\section{A ontologia e a tecnociência}

Heidegger denunciou o esquecimento do Ser. A grande novidade de seu pensamento está no fato de haver desmontado a estrutura da filosofia ocidental, que, segundo ele, desde Platão até Hegel, erigiu-se como a ciência do ente. Nela, o real está disponível como um objeto exterior. Ele é apreendido, dissecado e apossado pelo sujeito que o conhece, e que o transforma e o expressa segundo as categorias do pensamento solipsista. A metafísica e, em consequência, as ciências modernas, produziram a técnica como ciência, e a tecnociência está se independizando do "mundo da vida". $\mathrm{Na}$ esteira da Ontologia heideggeriana, o que nos interessa salientar é que o problema desse objetivismo não está na técnica e na ciência como tais. A questão está em que a tecnociência está se transformando em produto de 
consumo, tomando a configuração de um pacote de produtos que vai do megatécnico ou nanotécnico, dependendo das demandas do mercado. A cultura contemporânea, na rinha da indústria biotecnológica, tendo assegurado o domínio das técnicas da reprodução da vida e da apropriação do mundo, é indiferente a que essa tecnologia possa estar à disposição somente para alguns que podem pagar pelo que ela traz de sofisticação.

A robotização do real e, consequentemente, da produção revela o grau a que se pode chegar quando os artefatos são capazes de se responsabilizar pela responsabilidade do seu fabricante e até mesmo pela sua irresponsabilidade diante de sua criação. Enfim, a poiésis vai se tecnicizando a ponto de decretar sua maioridade em relação à matriz simbólica a partir da qual ela nasceu. E, por outro lado, vê-se as metalinguagens se tornarem asimbólicas ao tentar fazer da poiésis o bode expiatório da exacerbação tecnicista do mundo. Entretanto, se a tecnolatria parece louca, a tecnofobia é irracional. Ambas se afastam da simbólica da mediação da palavra, que é ao mesmo tempo linguagem e técnica.

\section{A mesmidade da técnica e da linguagem}

Levinas refere-se a um outro esquecimento mais antigo do que o do Ser e que por isso impede que a poiésis possa de fato recuperar sua significância a partir da sua intriga com o simbólico. Para ele, o Ser, ao voltar à sua aparecência, graças à diferença ontológica heideggeriana, não deixa de revelar seu absurdo, a saber, o fato de que a "existência ou a verbalidade do ser possa se dizer sem que haja existentes" (LEVINAS, 1994, p. 28). O problema da tecnociência não é apenas um problema ontológico no qual a ciência se tornou refém da própria técnica perdendo sua referência ao Ser, mas é eminentemente ético, como também o é o problema das metalinguagens

3 Esse termo é utilizado muitas vezes por Levinas quando ele quer se referir à filosofia heideggeriana. Heidegger pensou a diferença ontológica, mas continua fiel ao pensamento do idêntico ou do igual, ou seja, sem pluralidade, uma vez que tudo se diz no Ser e como Ser; tudo se reduz ao igual ao Ser e, portanto, ao que é o Mesmo de sempre. Na mesmidade do Ser não há lugar para a alteridade. Ao contrário, para Levinas, o Mesmo e outro em certo sentido são antagônicos, já que o outro está fora do Ser!

Rev. Pistis Prax., Teol. Pastor., Curitiba, v. 2, n. 1, p. 13-40, jan./jun. 2010 
RIBEIRO Jr., N.

alegorizantes do real. Na verdade, quando o outro desaparece do imaginário de uma cultura da mesmidade ${ }^{3}$ como a nossa, a busca compulsiva da precaução e da previsão não são senão outra maneira de manifestar sua indiferença ao processo de esvaziamento da nossa "arriscada" humanidade. Esse tipo de esquecimento ocorre não tanto por culpa da ciência e da técnica que nasceram do símbolo e da palavra, mas porque estamos aprendendo a ver o outro, isso é, aquele que não tem poder sobre quem tem poder sobre a técnica, como inabsorvível e improdutivo e, portanto, sem poder de troca. Nesse caso, o outro aparece como um indesejável.

A interpelação que vem da alteridade sempre desinstala e deflagra em nós verdadeira "an-arquia" quanto à nossa compreensão do modo de estar no mundo. $\mathrm{O}$ outro aparece como alguém que está aquém ou além de qualquer principio de inteligibilidade ou de organização, antes e depois do Ser, antes do mundo, da natureza e do cosmos. Seu aparecimento não deixa de desconstruir a lógica da técnica e da metalinguagem. Nesse outro regime, elas não podem jamais perder sua alteridade sem se tornarem alienadas de si. Melhor dizendo, a técnica e as metalinguagens recebem daquele que é anterior ao mundo o significado do seu "outro de si". É o outro que permite que a técnica e a linguagem não estejam referidas a si mesmas ou absolutamente autônomas em relação ao humano. Da sua alteridade emerge o caráter práxico da poiésis. Sua fabricação é para que o outro não pereça e para que, não sendo aniquilado, possa recriar existência bem melhor por meio da qualidade técnica que a vida tem em sua dinâmica. Para que o outro venha ao mundo e nele desabroche. Para que o mundo seja simbolicamente habitável como lugar da fruição e da morada dos "alimentos terrestres" e, por que não, de alimentos tecnocientíficos quando ligados ao mundo do símbolo.

\section{A natalidade e a banalidade poiética do mal}

Inseparável do alheamento do outro aparece o esquecimento da vida, como nos sugere Hannah Arendt. A cultura contemporânea vê no ser-para-amorte um forte atrativo porque o Nada da morte oferece certa comodidade. Ele suscita um horizonte de sentido e um projeto em que tudo pode ser construído em função da lógica do Ser. Bem ao contrário, no ser-para-a-vida

Rev. Pistis Prax., Teol. Pastor., Curitiba, v. 2, n. 1, p. 13-40, jan./jun. 2010 
a "condição humana da natalidade" (ARENDT, 2002, p. 191) abre um horizonte imprevisível de promessas graças ao aparecimento ininterrupto de novos nascimentos ${ }^{4}$. Cada pessoa que vem ao mundo impede que algo ou alguém se arvore ao direito de ter nas mãos a história como se ela pudesse ser transformada em produção de uma série de autômatos repetidores de um mundo mimético, estéril, sem milagre e sem graça.

Por tudo isso, as últimas décadas têm se confirmado como uma época bem propícia para que a obliteração da simbólica possa dar suas caras sem medo e sem reserva. Trata-se de uma época do absurdo dos esquecimentos: uma época que esqueceu que esqueceu. Esse esquecimento se deve ao fato de que a humanidade e a responsabilidade ética estão se estranhando no mundo da vida e na vida do mundo. A tecnolatria, tanto na sua vertente tecnicista como na sua versão linguística, aparece aqui como uma sangria desatada. Estaríamos vivendo numa espécie de banalidade poiética do mal?

Todos esses esquecimentos aparecem de maneira condensada em nossa cultura porque a simbólica, linguagem do símbolo, realidade mais expressiva da condição humana associada à palavra, está em declínio. Num contexto em que o real pode ser reduzido à medida $\mathrm{e}$ a linguagem a estruturas, indiferentes às camadas mais profundas do humano e do mundano, há menos espaço para que diferença e a diversidade possam se revelar. O outro, a vida, o real deixam de ser significantes para se tornarem significados de signos vazios. O mal, parafraseando Hannah Arendt, seria essa indiferença completa à alteridade e essa indiferenciação ou espécie de achatamento do mundo que uma poiésis meramente técnica e metalinguística produzem através da força de seus meios e de seus executores. Nesse sentido, a expressão acabada da poiética do mal seria aquela em que a reificação da palavra e do mundo das relações termina se tornando legitimadas pelo discurso técnico e pela técnica do discurso.

4 LEVINAS, 1994, p. 17. O filósofo, referindo-se ao tempo, dirá que ele é "essencialmente um novo nascimento". Com isso pretendia afirmar que há tempo lá onde estamos em relação com o outro humano, na história humana. Ora, sem estarmos referidos aos outros, estamos entregues à morte, ao a-temporal, à eternidade. Em outras palavras, só há tempo onde há finitude. Onde não somos eternos ou onipotentes. Só há tempo se há responsabilidade ética. O tempo nasce da irrupção do outro como Por-Vir que, aparecendo no presente, nos possibilita responder ao dom da sua chegada. Assim, tempo, outro e ética são absolutamente inseparáveis. Conforme também ARENDT, 2002, p. 190.

Rev. Pistis Prax., Teol. Pastor., Curitiba, v. 2, n. 1, p. 13-40, jan./jun. 2010 
RIBEIRO Jr., N.

Entretanto, como a palavra sempre é da ordem do "disfarce do milagre", ou seja, do homem que fala se pode esperar o inesperado, então ele, ao falar, torna-se capaz de "realizar o infinitamente improvável" (ARENDT, 2002, p. 191). O "novo sempre acontece à revelia da esmagadora força das leis estatísticas e de sua probabilidade, que para fins práticos e cotidianos, equivale à certeza" (ARENDT, 2002, p. 191). Assim a palavra introduz o inédito quando parece que o mal se apossou do mundo. Ela sempre poderá introduzir uma certa "des-ordem" no real e interromper o ciclo natural do fenomênico, do já dito e do banal. Nesse sentido, o milagre do poder começar o mundo pela ação/ palavra se refere ao ético e não propriamente ao religioso. É a ação/palavra que devolve a capacidade de recolocar a questão do "des-igual" e que incita a tratar o desigual com desigualdade. A palavra existe porque existe criação. Sem a palavra iniciadora e mediadora, a preocupação pelo outro deixaria de nos preocupar e a poiésis técnica e a linguística a-poiética nos desocupariam dessa atenção a ele. Na cultura hodierna há fabricantes de palavras, produtores de discursos, mas a ação já não é ação de quem "se" fala, porque quem fala sem "se" dizer torna-se incapaz de reconhecer a alteridade que interpela com sua ausência e com sua invisibilidade.

\section{O sujeito "como" responsabilidade}

Carregar tanto as tintas sobre a situação da cultura contemporânea não pareceria cair numa visão sombria do real e, portanto, irreal? Entretanto, não é intenção deste artigo tratar o real como se ele fosse unívoco, ingenuamente dando a mão à palmatória da crítica da pós-modernidade. É ela que tem consagrado aquilo que a antecede como sendo uma "cultura do terror", mesmo quando a modernidade exaltara a autonomia (LIPOVETSKY, 2004, p. 83). A hipérbole tem sempre a força de aproximar os contrários. Graças à ambivalência do real, tem-se uma chance ímpar de acreditar que, na medida em que o indivíduo aparece mais vulnerável diante da absorção pelas técnicas, linguagens anônimas e pelos discursos juridicistas, tanto mais se torna possível o aparecimento da ética. Essa ética não aparece tanto como ética "da" responsabilidade (SIMON, 1993, p. 89), nos moldes do pensamento de Max Weber e de P. Ricoeur, mas da ética "como" responsabilidade.

Rev. Pistis Prax., Teol. Pastor., Curitiba, v. 2, n. 1, p. 13-40, jan./jun. 2010 


\section{A sensibilidade e a vulnerabilidade}

Parece inegável: a fragilização do ser humano em nossa cultura traz sério desconforto e, às vezes, grande angústia. Instaura-se uma situação propícia para a irresponsabilidade quando o indivíduo já não coloca pra si a questão da autonomia, da lei da razão, do dever do agir, etc.

Entretanto, se a condição humana hodierna parece marcada pela despretensão quanto aos ideais da razão, a incerteza quanto às utopias, a insegurança quanto ao futuro pela des-teleologização e a ausência de fundamento diante da perda das grandes narrações, e mais, uma vez que o homem pós-moderno se vê jogado na trama da linguagem sem proteção diante das intempéries dos conceitos e das formas linguísticas, tanto mais sobressai o caráter sensível, corpóreo, afetivo como lugar inalienável dessa mesma condição no seio de um emaranhado de fios sem meada.

Em outras palavras, quanto mais indefeso e mais sem horizonte se encontra o indivíduo da cultura contemporânea, tanto mais está exposto às "figuras das alteridades". A partir dos interstícios da linguagem, essas figuras escapam do "campo de forças" ou das teorias petrificadas que aquelas construíram. As figuras de alteridade, com contornos tão diversificados, se manifestam como palavras poéticas e proféticas ao sujeito despido em sua nudez sem palavras. Acontece aí um promissor esvaziamento da visão juriscizante da responsabilidade. Essas figuras não vêm preencher carências. Elas irrompem diante do sujeito emudecido porque se colocam fora do regime dos discursos estruturalistas prontos e acabados.

Na medida em que o homem parece mais sem projetos e sem esperar nada de si e de ninguém, a alteridade poderá revelar-se não como aquela que culpabiliza, que condena, que se impõe através do aparato legal, mas como vulnerabilidade na pequena palavra que sai do seu corpo. Ela revela a nudez e a fragilidade do outro em seu "dar-se e retirar-se" (LEVINAS, 1994, p. 67).

\section{O "ad-vento" da alteridade}

O advento do outro pode deflagrar uma alteração no núcleo do sujeito narcísico (LEVINAS, 1988, p. 178). Aquele que outrora se encontrava sem recurso e sem defesa diante da antropofagia dos discursos técnico- 
estruturalistas e das linguagens alegorizantes vê-se despertado do sono da indiferença ou da perda de identidade, ao ser tocado pelo corpo/palavra do outro. Diria mesmo que, na medida em que cresce a força sufocante das metalinguagens, mais os valores tênues da condição do homem contemporâneo poderão solapar a força dos discursos explicativos sobre o homem, sobre o mundo e sobre Deus. Nesse lugar frio de conceitos sem viço, o outro se apresenta como rosto, luz intermitente "as-sinalando" o Mesmo com seu signo-palavra. Como bem expressou Levinas,

no rosto o expressado assiste à expressão, expressa a sua própria expressão, permanece sempre dono do sentido que ele mesmo dá. Ato puro à sua maneira, ele se nega à identificação, não entra no já conhecido e dá, como diria Platão, assistência a si mesmo, isto é, fala. A epifania do rosto é toda ela linguagem. (LEVINAS, 1988, p. 173).

Quanto mais vulnerável se encontra o indivíduo diante da linguagem ardilosa do tecnolinguístico, tanto mais afetado pelo outro como "linguagem do rosto". Graças ao seu corpo silencioso, sem palavras, ávido da palavraação daquele que vem bem de lá de fora das armadilhas das linguagens sem nomes próprios, o sujeito pode experimentar-se acolhido por aquele que vem para perdoá-105, para "dar-se através" dessa relação. O outro se revela e "desvela" a significância do mundo e da vida. É exatamente porque ele irrompe no mundo e no tempo, nos "per-doando" de seu esquecimento, que o indivíduo se vê liberado da culpa da responsabilidade que o obriga a responder em juízo diante do que fez e até do que não fez (RICOEUR, 2000, p. 624). Nesse sentido, a culpabilização é filha dos discursos herméticos sobre o humano, o sagrado e o mundano.

5 ARENDT, 2002, p. 249. A faculdade de perdoar não é da ordem da religião. Ela está associada à Política, ao espaço público. Ela é indissociável do problema da irreversibilidade de nossa ação, isto é, a "impossibilidade de se desfazer o que se fez, embora não se soubesse nem se pudesse saber o que se fazia". Segundo Arendt (2002, p. 249), "se não fôssemos perdoados, eximidos das conseqüências daquilo que fizemos, nossa capacidade de agir ficaria, por assim dizer, limitada a um único ato do qual jamais nos recuperaríamos: seríamos sempre vítimas de suas consequiências"

Rev. Pistis Prax., Teol. Pastor., Curitiba, v. 2, n. 1, p. 13-40, jan./jun. 2010 


\section{As ciências da vida e o simbólico}

Ao se referir à perda do simbólico na cultura hodierna, este estudo pretendia contrastá-la com aquela outra constatação que também parece inegável, a saber, que a situação de fragilidade da nossa humanidade oferece possibilidades inimagináveis para que seja interrompido o ciclo desse esquecimento do esquecimento.

\section{As ciências da vida e seu risco}

Pensamos que especialmente no campo das "ciências da vida", em que o risco não pode ser ignorado e muito menos descartado - uma vez que aparece aí de maneira quase palpável o humano e, ao mesmo tempo, o invisível dessa humanidade que se encontra em sua vulnerabilidade máxima -, é que, paradoxalmente, a desobliteração da simbólica poderá acontecer. Não porque a programamos, mas porque a própria palavra que vem do silêncio pode irromper, apesar de termos sido ensinados a viver de todas as formas de tagarelice em nossos discursos técnico-jurídicos ou metalinguísticos alegorizantes. É a palavra que vem do outro que nos possibilita voltar ao símbolo da palavra e à palavra do símbolo. Tanto a poiésis da técnica e do jurídico como as metalinguagens são "re-encantadas" pela ação-palavra criativa do outro que nos instiga a dar um passo para fora da mesmidade. Sempre nos é dado soerguer das cinzas do esquecimento do simbólico quando a alteridade nos recorda, de dentro mesmo de nossa vulnerabilidade, que somos capacitados para promover o outro na sua vulnerável finitude.

\section{A manipulação do imanipulável}

Sem dúvida, todos aqueles que estão envolvidos, seja na manipulação da vida - humana, animal, mundana -, seja como paciente da pesquisa ou sujeito pesquisador, partilham da condição de "vulneráveis" interpelados pela palavra do outro. Essa condição cria uma cumplicidade entre os vulneráveis, possibilitando tecer espontaneamente redes de ação/palavra e, portanto, de pessoas que aparecem "como" responsabilidade bem antes de serem 
responsabilizadas pelos erros ou acertos cometidos. A responsabilidade aqui não é apenas um adjetivo ou um atributo do sujeito agente que fala. Ela mesma constitui aquele que fala. Ela se identifica com a própria unicidade daquele que deseja responder à afecção e ao fascínio que a alteridade põe nele.

Tudo que diz respeito à vida afeta tanto o paciente da ação de alguém quanto esse mesmo que age. Somos "afeccionados" pela proximidade daquele ou daquilo (alteridades) que não fomos nós que produzimos com as nossas mãos. Quando manipulamos a vida, não manipulamos só algo ou alguém que virá, mas manipulamos o que fomos, somos e seremos. Somos seres de símbolos. A manipulação está prenhe de significação por conjugar em si o caráter técnicopoiético e o caráter linguístico da poiésis. Por isso ela tem sempre um caráter de irreversibilidade (ARENDT, 2002, p. 248). Ela crava no real uma marca indestrutível. Toda ação-palavra será sempre bem-vinda ao mundo como obra criadora quando ela não almeja desfigurar, destruir ou "de-generar" a palavra do outro que antecede toda criação da linguagem e da técnica.

Diante da possibilidade da manipulação cada vez maior que a póiesis técnico-jurídico e os metadiscursos colocam ao nosso alcance, haverá, em contrapartida, a irrupção incontida e incontável do imanipulável, que na sua fragilidade sempre interditará as tentativas de coisificá-lo. Ele sempre nos recordará (recordar $=$ trazer ao coração de maneira benévola) as marcas que nossas ações deixaram, deixam e poderão deixar nos outros e no mundo. Por isso mesmo, na manipulação há sempre, por mais paradoxal que possa parecer, um caráter paralisador (ARENDT, 2004, p. 243) Somos paralisados em relação ao poder de que dispomos diante do outro. Por um lado, ele interrompe o curso ou encadeamento de nossas ações. Por outro, inaugura em nós uma nova maneira de agir e de falar diante de seu falar e, consequentemente, nossa nova maneira de "pensar".

\section{O cálculo como "cuidado"}

Cumpre salientar, então, que é a partir da relação com o diferente que surge, de dentro de cada um, uma preocupação pela limitação de nossa pretensa ilimitação ou um limite que nos damos sobre o excesso de cálculo ou de alegorias metalinguísticas (SAVATER, 2004, p. 159) sobre o que $a$ priori é incalculável. Já não precisamos nos apegar à norma extrínseca ou à lei positiva para barrar nossas ações maléficas ou para prevenir contra o mal

Rev. Pistis Prax., Teol. Pastor., Curitiba, v. 2, n. 1, p. 13-40, jan./jun. 2010 
que porventura possamos realizar através da poiésis da linguagem ou da técnica. Somos nós mesmos que aprendemos a medir os limites que nos damos ou que damos às nossas ações graças à em-patia (pathos) que o outro causa em nós. Somos convencidos de dentro de nós mesmos a optar por um modo de autolimitação diante do "não manejável que o humano deve manter para o humano" (SAVATER, 2004, p. 159).

Se há lugar para o cálculo no âmbito da simbólica e da palavrarelação, há somente para que interditemos aquilo que nos interdita de acolher o outro. Não se trata aqui somente do genérico respeito ao outro e aos seus direitos, à sua autonomia, mas da beneficência e bem-querência diante do outro. Aqui aparece a especificidade da responsabilidade ética em que a "estima do outro" suscita em nós um cuidado especial e concreto pela vida de cada um que nos interpela. Trata-se do cuidado pela diferente palavra em circunstâncias imprevisíveis que nos chega vindo de rostos tão diferentes, irrepetíveis, únicos.

A alteridade do paciente diante do médico não é a mesma que a do aluno diante do professor e assim sucessivamente. No caso específico do médico que responde diante da interpelação do paciente, ele não só responde pelo bem do outro, mas pelo bem da instituição que foi feita para o bem do outro e na qual ele exerce a profissão, diante do sistema de saúde em que ele está inserido etc. Cuidar do bem do outro tem que estar circunscrito ao seu rosto, mas esse cuidado deve ser ampliado e associado ao seu caráter institucional. Somente assim o cuidado pelo outro será assumido por todos numa rede de beneficência. A partir dessa perspectiva, o caminho inverso dá o que pensar. Uma instituição de saúde é interpelada a pensar no rosto mesmo quando ele está ausente. $\mathrm{O}$ cuidado e a beneficência estão sendo pensados em função daqueles que chegarão a qualquer momento, desejosos de serem bem tratados.

\section{A bioética e a "re-significação" da simbólica}

Nesse contexto, a bioética emerge como âmbito privilegiado da palavra e da ação. Ela é antes de tudo um lugar de "re-significação" da simbólica. 
No espaço que ela cria de circulação incessante da palavra, ela nos convida a colocar-nos diante da alteridade que sempre causa em nós uma "as-signação" ou uma "as-sinalação": "eis aí o outro", dizemos (o paciente, a criança, o moribundo, o indefeso). Ou seja, no âmbito da bioética a ideia do outro passa ou transita entre nós deixando suas marcas, signos, pegadas, rastros e, ao mesmo tempo, nos convoca a comparecer diante de sua palavra escondida e indefesa para que respondamos por sua vida.

\section{A comunidade de ação e palavra}

Parece evidente que, por um lado, a bioética não pode deixar de anunciar e testemunhar o caráter vulnerável de nossa humanidade e da vida no mundo/vida do mundo. Por outro, insiste sobre a necessidade de "partilhar perplexidades" (ARENDT, 2004, p. 258) mais do que encontrar soluções apressadas diante dos riscos próprios da responsabilidade ética. Ao fazermos perguntas para as quais não sabemos de antemão as respostas, não nos vemos, por isso, imobilizados em nosso agir/falar. Ao contrário, impelidos pela interpelação que as marcas e as pegadas do outro sempre deixam em nós, continuamos abertos para novas e intermináveis perplexidades. Diante delas, nossa responsabilidade está continuamente se fazendo e refazendo.

Além disso, como é impossível desvincular o imaginário da bioética de uma comunidade de sujeitos agentes/falantes, com toda a riqueza que traz em si graças ao seu caráter polifacético e transdisciplinar, essa comunidade sempre provocará em nós uma "pré-ocupação" fundamental. A saber, como falar-agir diante da exposição do humano e da vida quando estamos corpo a corpo e face a face, diante da possibilidade de manipular o passado, o presente e o futuro daqueles cujo total controle não poderemos jamais ter? O fato é que eles jamais perdem sua alteridade mesmo quando podemos dispor de meios eficazes, sejam eles técnicos ou linguísticos, para decidir sobre seu destino. Há na ação/palavra algo que nos faz aproximarnos dos outros, seja daquele que já veio e tornou-se presente e que continua alteridade pela sua palavra, seja daquele que está por vir e cuja chegada somos convidados a desejar. Em ambos os casos, o outro intervém no tempo e nos investe de responsabilidade ética.

Rev. Pistis Prax., Teol. Pastor., Curitiba, v. 2, n. 1, p. 13-40, jan./jun. 2010 


\section{A "ausência" do outro}

A bioética pretende nos colocar na busca infindável do rastro do invisível ou do ausente com o qual temos de aprender a querer bem graças à sua promessa e à sua bondade original. A ausência do outro sempre cava em nós o desejo para que não nos cansemos de acolhê-lo. Diante dessa ausência, o outro não nos aparece como aquele que nos quer levar ao tribunal. A alteridade coloca em questão aquela ideia que herdamos e que nutrimos em nossa cultura romântica de que ele sempre arruma um jeito de aparecer para nos tirar da angústia que causa a incerteza e o desconhecido.

Nessa perspectiva, a bioética aparece para proclamar a alteridade da alteridade, isto é, que a alteridade abre um buraco, um oco em nós e não nos complementa absolutamente. Do contrário nos acostumaríamos a tratá-la como óbvio e descartável. Seu reaparecimento incessante causa uma insegurança salutar em nós. Não podemos nunca dispor de sua alteridade. Ela cria em nós outra disposição até para compreendermos a maneira como dispomos de nós mesmos. Isso é fruto da salutar insegurança da falta. Uma falta que sempre está aí para nos lembrar que a única falta que não pode jamais nos faltar é a falta do outro. A bioética é certamente esse âmbito da palavra em que mais se tem de aprender a lidar com a falta que faz a falta do outro.

\section{A faculdade de pensar}

Segundo Arendt, essa possibilidade de lidar com o que não temos como posse nos é dada pela "faculdade de pensar" (ARENDT, 2004, p. 233). Essa mesma ideia foi expressa de outra maneira por Levinas ao referir-se ao "pensamento que pensa mais do que pensa" . A bioética é esse terreno onde a faculdade de pensar é constantemente recriada. "Pensar", na visão desses filósofos, não se reduz ao conhecer; não é simplesmente dominar o saber pela técnica, pelo contrato, pelo jurídico ou pelas linguagens que se nutrem de

6 LEVINAS, 1988, p. 172. Segundo ele, o outro coloca em nós a ideia do infinito. "Essa idéia é um pensamento que em todo instante pensa mais do que pensa. Um pensamento que pensa mais do que pensa é Desejo. O desejo 'mede' a infinitude do infinito".

Rev. Pistis Prax., Teol. Pastor., Curitiba, v. 2, n. 1, p. 13-40, jan./jun. 2010 
RIBEIRO Jr., N.

explicações às vezes vazias e impessoais sobre o real. Paradoxalmente, pensar é pensar o impensável. É pensar aquele que se reserva o direito de entrar e sair do pensamento do pensante.

Graças ao caráter sui generis do pensar, a bioética assume um estatuto ímpar no contexto de nossa cultura. Ela se erige como um elogio à responsabilidade ética, lugar do "pensamento" do outro. Elogio, porque a bioética está sempre atenta a que nosso desejo de responder pelos nossos atos e decisões diante do outro venha nutrida pela sua ausência. Essa ausência só pode ser acolhida por nós pela faculdade de pensar.

Nesses termos a "faculdade de pensar" é anterior à "faculdade de julgar”. (ARENDT, 2004, p. 257) A responsabilidade ética não se tece, em primeiro lugar, em função da obrigação diante do outro lesado por nós ou ao contrário. Nossa relação não é em primeiro lugar de vítima-juiz, em que o ausente exige ressarcimento pelos danos que lhe foram causados. A alteridade não é aquela que julga e que nos coloca diante da imputabilidade dolosa ou culposa de uma ação. Antes, ela desencadeia em nós o "pensamento do pensar" que nos inspira a buscar um lugar outro que o do abandono e da solidão que podemos impingir a ele.

\section{A responsabilidade coletiva}

A faculdade de pensar, tão presente e alimentada pela bioética, nos move na direção de uma responsabilidade ética coletiva. Estar diante do outro é estar diante de tantos outros que nos interpelam no rosto indecifrável. Todos nós respondemos pelos atos de todos que partilham da mesma comunidade de ação/palavra, embora não sejamos contados como culpados por aqueles atos que não cometemos (ARENDT, 2004, p. 213). E a bioética que dá sempre a pensar, nos faz ver que, anterior a qualquer dever, qualquer obrigação, há sempre a urgente necessidade de uma ponderação das conseqüências da nossa ação sobre os outros e o mundo.

Portanto, na responsabilidade coletiva as consequências de nossas ações/palavras partilhadas são assumidas pelos participantes das redes de açãodiscurso. Daí a importância e a necessidade de um "controle parcial" diante da imprevisibilidade de nossas ações. Esse controle nos permite criar certas "ilhas de certeza num oceano de possibilidades". (ARENDT, 2004, p. 256). Sem elas,

Rev. Pistis Prax., Teol. Pastor., Curitiba, v. 2, n. 1, p. 13-40, jan./jun. 2010 
viveríamos expostos à absoluta fluidez da ação. Não criaríamos uma tradição sapiencial entre o passado e o presente. Os outros não poderiam contar com as pequenas narrativas de nossas responsabilidades já inscritas na cultura. Não estaríamos realizando de fato nossa preocupação e nosso cuidado pelas gerações vindouras, com a espécie humana e com o mundo e o cosmos. (JONAS, 1992, p. 54). O cuidado necessita de espaços públicos, de expressões sociais e políticas em que discurso e ação se entrelaçam. E mais: sem essas "ilhas de certeza" que a tecnociência tem nos inspirado a buscar graças à sua preocupação com a operacionalidade, não protegeríamos o outro diante da opção sórdida de alguém ou grupo decidido a negar a si mesmo o desejo de poder nascer pela ação/palavra e querer também impedir que o outro nasça. O controle parcial normatizado pelas próprias ações/palavras da comunidade ética vem em socorro de todos os rostos vulneráveis à banalidade do mal. Esse controle visa a proteger, sobretudo, os mais vulneráveis dos vulneráveis. Eles são os rostos nus dos pobres produzidos pela nossa cultura, que às vezes tende a desfigurar ainda mais o rosto desfigurado.

Mesmo admitindo que a bioética tenha uma dimensão "pro-fética", ela há sempre de recordar que o controle parcial da imprevisibilidade de nossas ações não nasce e nem é fruto de um utilitarismo sem espírito e muito menos filho de um juridicismo deontologista que povoa cada vez mais o imaginário de nossa cultura. Graças ao caráter simbólico da técnica, o cálculo nasce de dentro mesmo de nossa ipseidade ética ${ }^{7}$ associada a uma certa operacionalidade. Ele se plasma a partir da responsabilidade colocada diante de cada novo pensamento que cada outro coloca em nós. A previsão e o compromisso com as consequências de nossos atos se nutrem dessa visão consoladora de estarmos diante da alteridade que nos libera do trauma da perseguição, ao mesmo tempo em que nos salva da armadura ou do endurecimento pragmático de um mundo de contratos e técnicas sem símbolo e de uma linguagem sem ação.

7 Termo utilizado especialmente pela fenomenologia e pela filosofia hermenêutica para opor-se à ideia da identidade como aquilo que é idêntico a si. Graças ao fato de a subjetividade ser constituída na relação com o mundo e com o outro, sua identidade é alterada e, portanto, é uma ipseidade ou um outro de si no contato com o diferente. Ou melhor, a identidade só é identidade porque a alteridade colocou no interior do eu um outro que não o eu solipsista. $\mathrm{O}$ outro não nos deixa voltar a nós sem que tenhamos sido marcados pela relação com ele e portanto, com o que nos é dado de fora.

Rev. Pistis Prax., Teol. Pastor., Curitiba, v. 2, n. 1, p. 13-40, jan./jun. 2010 


\section{CONCLUSÃO}

Resta-nos dizer duas palavras finais, embora sem a pretensão de serem conclusivas, sobre a questão da bioética. A primeira sobre a vulnerabilidade da condição humana, seja no seu início, seja no fim e seja também no que diz respeito ao cuidado da vida de qualquer que seja a forma com a qual ela se manifesta. Indubitavelmente teremos de lidar sempre com certo pudor quando deparamos com a nudez do outro. Sua fragilidade nos coloca diante do fio mais fino que separa o manipulável e o intangível; o perdão do irreversível e a promessa do imprevisível, entre o secular e o santo, entre a onipotência e a finitude, entre as normas e a transgressão. Nessa perspectiva, as ideias de uma capacidade de escolha ou prudência - a phrónesis, e de uma capacidade (social) de recriar a ação quando a norma já não dá mais conta da situação ética, a epiquéia, parecem inspiradoras diante da complexidade dos desafios éticos de nossa cultura. Em certo sentido, seu imaginário evoca o caráter transgressor da responsabilidade ética e a transgressão responsável aparece como condição necessária para que a "desobliteração" da linguagem do símbolo interrompa o caráter legalista da moral.

Uma segunda palavra. No contexto da bioética como espaço dessa “des-obliteração" almejada, o caráter religioso da nossa vulnerabilidade reaparece como qualidade e não como aquilo que bloqueia, que coage e que cerceia nossos atos. Na linguagem ostensiva do Sagrado e mesmo na linguagem ontoteológica sobre Deus, nos acostumamos a discursar sobre um objeto passível de ser conhecido e, consequentemente, de ser dominado. Ao mesmo tempo, em nome dessa teologia, aprendemos a evocar a intangibilidade da vida humana. A aporia da linguagem revela uma dicotomia que ainda hoje ronda a própria compreensão que temos do outro e de Deus. Em contrapartida, no contexto da bioética nos vemos interpelados a deixar-nos "afeccionar" pelo indizível que já coloca em nós a imaginação ${ }^{8}$ de um mundo querido como nossa morada (ethos/hábito) onde Deus e a humanidade não estão em concorrência e nem estão aí para interditar nossa ação e nossa palavra. Por

8 RICOEUR, 1986, p. 217. Segundo o filósofo, a imaginação, "longe de ser a 'louca da casa' que navega no irreal ou na simples reprodução imaginada do que está ausente, é o lugar mediador da inovação semântica". Nesse sentido, a "imaginação permite experimentar novas possibilidades de associação, novas maneiras de ver o mundo. Ela contribui para reescrever a realidade por meio da ficção".

Rev. Pistis Prax., Teol. Pastor., Curitiba, v. 2, n. 1, p. 13-40, jan./jun. 2010 
quê? Porque o Santo e o profano suscitam em nós o desejo de "amar o mundo" (ARENDT, 2002, p. 254) naquilo que ele tem de mais escondido e "in-visível" e que está Por-Vir. O amor ao mundo faz brotar em nós o "pensamento" de que diante do afã da incontida e frenética busca de certeza, programação e produção do homem e do mundo sem falhas e sem defeitos, as figuras de alteridade irrompem diante de nós. Elas nos interpelam a não temer a ética, isto é, a não temer a finitude e o risco da palavra e da ação; não temer abrir uma porta para o futuro em que a responsabilidade e a acolhida do outro não sejam ameaça nem incômodo ou acusação para nossa humanidade e nosso mundo. A bioética sempre poderá ser esse espaço fecundo do pensamento daquele que "pensa mais do que pensa". Pensar, falar e agir é maneira vulnerável de “des-obliterar" a simbólica.

\section{REFERÊNCIAS}

ARENDT, H. A condição humana. Rio de Janeiro: Forense Universitária, 2002. Responsabilidade e julgamento. São Paulo: Companhia das Letras, 2004.

BAUMAN, Z. O mal-estar da pós-modernidade. Rio de Janeiro: Jorge Zahar, 1999. ETCHEGOYEN, A. La vraie morale se moque de la morale: être responsable. Paris: Seuil, 1999.

HAMONIC, T. M. Morale et (post) modernité, chronique de philosophie morale. Revue Doctrinale de Théologie et de Philosophie, Toulouse, v. 98, n. 1, p. 133-165, 1998.

JONAS, H. Le principe responsabilitè: une éthique pour la civilization technologique. Paris: Cerf, 1992.

LEVINAS, E. Le temps et l'autre. Paris: Fata Morgana, 1994.

. En découvrant l'existence avec Husserl et Heidegger. Paris: Librairie Philosophique J. Vrin, 1988.

LIPOVETSKY, G. Os tempos hipermodernos. São Paulo: Barcarolla, 2004.

RICOEUR, P. Du texte à l'action: essais d'hermeneutique. Paris: Esprit; Seuil, 1986. . Lectures I: autour du politique. Paris: Seuil, 1988. 
RIBEIRO Jr., N.

La mémoire, l'histoire, l'oubli. Paris: Seuil, 2000.

SAVATER, F. A importância da escolha. São Paulo: Planeta do Brasil, 2004.

SIMON, R. Éthique de la responsabilité. Paris: Cerf, 1993.

Recebido: 04/09/2009

Received: 09/04/2009

Aprovado: 30/10/2009

Approved: 10/30/2009 